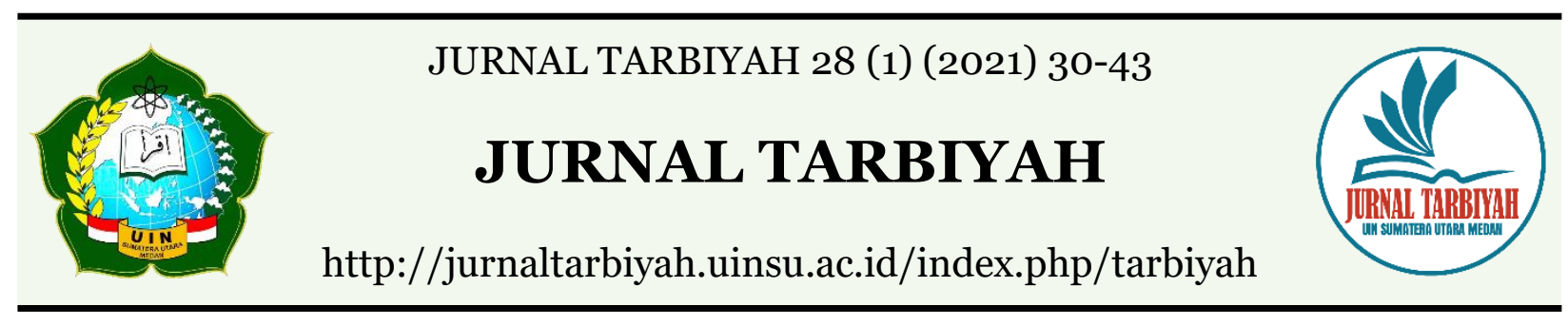

\title{
OPTIMIZATION OF FACILITIES AND INFRASTRUCTURE MANAGEMENT IN IMPROVING THE QUALITY OF LEARNING
}

\author{
Nurafni Siregar ${ }^{1}$, Aziza S. ${ }^{2}$ \\ ${ }^{1}$ State Islamic University SunanKalijaga, Yogyakarta, Indonesia \\ ${ }^{2}$ State Islamic University of North Sumatra, Medan, Indonesia \\ Email : ${ }^{1}$ Afnisiregarg6@gmail.com, ${ }^{2}$ aziza3532@gmail.com
}

DOI : 10.30829/tar.v28i1.905

Accepted: January 28th, 2021. Approved: June 28th, 2021. Published: June 30th, 2021

\begin{abstract}
Infrastructure is a standard of education considered and provided by every educational institution, because of complete facilities and infrastructure are a support for the learning process in an educational institution. Therefore, every educational institution must have feasible and useful in order to support the learning process. Effective learning is supported by complete facilities and infrastructure. Every school community should maintain and maintain existing facilities and infrastructure and also optimize the management to create durable school facilities and well maintained. The well service of these facilities and infrastructure is benefit to the school community, especially students in their learning. The main purpose of managing school facilities and infrastructure is to provide good and professional services in creating the effective and conducive school environment.
\end{abstract}

Keywords: facilities, infrastructure, learning, education 


\section{INTRODUCTION}

Education is a conscious and planned effort to create a learning situation and process which make students can develop their potential to have religious spiritual strength, self-control, personality, intelligence, noble character, and skills needed for themselves, society, nation, and society (UU SISDIKNAS No. 20 of 2003) about concerning quality improvement is one of the pillars of education development in Indonesia. The importance of education as a place for students to be able to develop their interests and talents, so to be able to achieve the goals of education itself, namely: as the formation of one's character, it requires a learning process that is in sync with the needs of students and the general public, and supported by adequate facilities and infrastructure in accordance with the decision standards of the Ministry of Education (Prastyawan, 2016: 02).

Schools are required to improve their quality in various of learning, especially improvements in the management of facilities and infrastructure to support learning. Given the importance of facilities and infrastructure in learning activities, students, teachers, and schools are directly related. The existence of adequate facilities and infrastructure will be able to help students in their learning, because not all students have good intelligence so that the use of facilities and infrastructure in learning to help them be better understand existing learning (Yulius, 2020: 03).

Safingudin (2020:242) said that the success of educational programs through the teaching and learning process is strongly influenced by many factors, one of them are the availability of adequate educational facilities and infrastructure accompanied by optimal utilization and management. Educational facilities and infrastructure are one of the important and main resources in supporting the learning process in schools, It is necessary to improve their utilization and management to achieve expected goals .Today, it is still often found that many educational facilities and infrastructure owned by schools are accepted as assistance, both from the government and the community, they are not used optimally and can not be used in a long time. This is caused by the lack of concern for the facilities and infrastructure owned and the absence of adequate management.

Every educational institution must realize that success in learning activities in schools is strongly influenced by the availability or incompleteness of facilities and infrastructure in education. In terms of improving education in Indonesia, it will be difficult to implement if the existing facilities are incomplete or poorly managed in the school. Sometimes an educator also does not optimize the existing facilities and 
infrastructure in the learning process because of several factors, spending of energy, time, and etc. furthermore, a few teachers or other staff do not understand how to use the existing facilities or infrastructure. As for facilities and infrastructure, not all schools that have received assistance from the government and the community can meet the standards of facilities and infrastructure that have been determined in Government Regulation No. 19 of 2005. This situation is due to the lack of awareness of the school community towards the fulfillment of facilities and infrastructure as well as owned and less than optimal management of facilities and infrastructure.

According to Mulyasa (Nasrudin, 2019:15-23) educational facilities are equipment and supplies that are directly used and support the educational process, especially the teaching and learning process, such as buildings, classrooms, tables, chairs, and teaching tools and media. Thus, educational facilities have good role when the use of these facilities is carried out by the educators concerned optimally. Barnawi argues that educational infrastructure is all basic equipment that indirectly supports the implementation of the educational process in schools. Therefore, educational facilities and infrastructure are an integral part of supporting the implementation of the learning and teaching process properly and optimally.

Sairi \& Safrijal, (2008:20) states that the achievement of effective learning requires the management of school facilities and infrastructure such as tools and media used as supports. In addition to educators, facilities are the most important part of education and learning. Thus, learning will never run properly without adequate facilities and infrastructure. Therefore, the management of facilities and infrastructure is very necessary, because with the management of educational facilities and infrastructure it will be more empowered and can also improve the quality of learning in schools.

\section{LITERATURE REVIEWS}

Megasari (2014:639) states that the management of educational facilities and infrastructure is an activity to create and maintain optimal conditions for the learning process to occur. Through development of science and technology, teaching and learning activities require management efforts in educational facilities and infrastructure. As an indicator of the success or failure of the process of achieving an educational goal. It is influenced by the management of school facilities and infrastructure by the school. 


\section{Management of Educational Facilities and Infrastructure}

Law of the Republic of Indonesia No. 20 of 2003 about the national education system "Each formal and non-formal education unit provides facilities and infrastructure that meet educational based on the growth and development of physical potential, intellectual, social, emotional, and obligations o students" (Law of the Republic of Indonesia Year 2003). And also RI Government Regulation No. 19 of 2005 concerning National Education Standards Chapter VII article 42 paragraphs 1 and 2, namely:

- Each educational unit is required to have facilities include: furniture, educational equipment, books and other learning resources, consumables and equipment needed to support an orderly and continuous learning process.

- Each educational unit includes: land, classrooms, leadership rooms, teachers' rooms, library rooms, laboratory rooms, canteens, places for sports and places of worship, playgrounds, recreation areas, and other spaces needed to support an orderly learning process and sustainable. (PP RI 2005).

Bafadal (Ananda \& Kinata, 2017:20) explains that educational facilities are all equipment, materials and furniture that are directly used in the education process in schools, while educational infrastructure is all basic equipment that indirectly supports the implementation of the education process in schools. Meanwhile, according to E. Mulyasa, educational facilities are equipment and supplies that are directly used and support the educational process, especially the teaching and learning process, such as blackboards, markers, erasers, stationery, books, and teaching media. While educational infrastructure are facilities that indirectly support the course of an educational and teaching process in an educational institution, for example, such as buildings, classrooms, yards, school gardens, and so on. However, if the infrastructure is used directly for teaching and learning activities, for example the school garden is used for biology learning activities, then the school garden becomes an educational facility.

According to Kompri (2015: 242) that broadly speaking, educational facilities and infrastructure in schools can be clarified as follows:

1. Land, is a plot of land used to build a school building.

2. Room, is a place used to carry out learning activities, and administrative activities.

3. Furniture, is a set of benches, tables, cabinets, are used to carry out learning activities and administrative activities. 
4. Tool, is something that is used to make certain things for the implementation of learning activities and administrative activities.

5. Practice materials, all kinds of natural and artificial materials used for practice.

6. Teaching materials, reading sources that contain knowledge to support learning activities.

7. Sports facilities, both outdoors and indoors.

Management of existing infrastructure facilities in schools is expected to help and maintain school facilities, namely by planning, procurement, maintenance, and elimination of educational facilities and infrastructure.

a. Facilities and infrastructure planning

According to Safingudin (2020:220) Educational facilities and infrastructure planning activities are very important in order to avoid unwanted mistakes. The planning process must be carried out carefully and thoroughly both with regard to the characteristics of the facilities and infrastructure needed, the amount, type, and constraints (benefits obtained), as well as the price. Careful planning is very influential on the implementation of activities to achieve the goals that have been set.

Kurniawan (2017:16) also added that management planning includes the management of KBM facilities from a series of sequential activities starting from (1) data collection and processing, (2) analysis of needs for facilities, (3) formulation of facility requirements, (4) determination of priority needs facilities, and (5) details of the facility requirements plan.

b. Procurement of Facilities and Infrastructure

The procurement of educational equipment is basically an effort to realize the equipment procurement plan that has been prepared previously. Kurniawan (2017:16) also mentions that based on the type, the procurement of facilities and infrastructure includes: (1) procurement of premises, (2) procurement of buildings; constructing a new building, buying a building, renting a building, or receiving a building grant, (3) Procurement of equipment; buy, make their own, and receive grants (4) Procurement of educational ATK; Buy, receive a grant or recycle.

c. Maintenance of Facilities and Infrastructure

Maintenance of facilities and infrastructure is education is an activity to carry out the management and arrangement of facilities and infrastructure to make sure that all facilities are in good condition and ready to be used efficiently and successfully in 
achieving educational goals. Maintenance is an activity to guard or prevent damage to an item. So that it is always in good condition and ready to use.

Matin \& Fuad (2016: 89) say that currently many buildings or buildings are being built but there is no maintenance on them so they are vulnerable to damage such as tables and chairs. Therefore, this is the reason why it is necessary to maintain the existing facilities and infrastructure in an institution, so that all existing facilities and infrastructure can be maintained and ready to be used.

d. Removal of Facilities and Infrastructure

Ibrahim Bafadal (Kurniawati \& Sayuti, 2013:103) argues that definitively, the elimination of educational facilities and infrastructure is an activity to remove institutional property (it can also be state property) from the inventory list by means of the applicable laws and regulations. As one of the activities in the management of educational facilities and infrastructure.

According to Nasrudin and Maryadi (2018: 20), the reason for the elimination of educational facilities and infrastructure is having several considerations made for the elimination, such as: in a damaged state, repairs require relatively large financing, and are not depend on the needs of the school. Thus, the deletion is carried out for facilities that cannot be used more/ Apart from this situation, it is also save the budget and free up educational space. In addition, the abolition also has another goal, namely to ease the workload of educators and education staff in the school.

\section{Quality of learning}

Darmastuti \& Karwanto (Jurnal, 2014:10) said that teachers are an important factor in improving the quality of learning. However, this does not mean that the existence of other elements is not so important for improving the quality of education in schools. Teachers need professional services in the field of facilities and infrastructure in implementing their abilities to the fullest.

Goetsch and Davis cited by Tjiptono (2000), make a broader definition of quality or quality, namely "Quality is a dynamic condition associated with products, services, people, processes, and the environment that meet or exceed expectations." End of a long process carried out by an institution. Quality is also a guarantee from an institution to its customers, where in education customers expect quality from learning. (Setiawati, 2018:08). 
According to Winkle as quoted by Eveline Siregar in her book, Learning Theory, states that learning is a set of actions designed to support the student's learning process, taking into account extreme events that play a role in a series of ongoing internal events experienced by students. Setiawati, 2018:09). Learning is an effort so that by one's own volition a person can learn, and make it one of the necessities of life that cannot be abandoned.

According to Memorata \& Susanto (2021:03) that the quality of learning is the level of effectiveness of learning in achieving educational goals. In the learning process the main goal is the achievement of predetermined goals. To achieve the achievement of learning quality, the teacher or school must utilize the components of the learning process optimally.

\section{RESEARCH METHODS}

Research on the Optimization of Facilities and Infrastructure Management in Improving the Quality of Learning according to Sari (2020) is to use a research method in the form of library research, where library research is a research activity carried out by collecting information and data with the help of various kinds of materials in the library such as reference books, similar previous research results, articles, notes, and various journals related to the problem to be solved. Activities are carried out systematically to collect, process, and conclude data using certain methods/techniques to find answers to a problem.

The sources of data used in this research are books, journals, and internet sites that are related and relevant to the topic of discussion.

\section{RESULT}

Trisnawati (2019: 63) said that the learning process is strongly influenced by several factors, so that the success of educational programs can be achieved properly and smoothly, one of which is educational facilities and infrastructure. Every school is required to have adequate facilities and infrastructure, because of every educational unit realize that organizational goals must be supported by complete facilities and infrastructure and are also ready to be needed. Facilities and infrastructure can affect students' learning abilities, because with the availability of existing facilities and infrastructure in schools students can learn through existing and complete facilities in schools such as libraries, computer laboratories, science laboratories, sports fields, and 
so on. Therefore, these facilities and infrastructure can be utilized and can also increase the knowledge of students. Therefore, it is necessary to have good and optimal management of facilities and infrastructure so that they can be used in the long term in supporting learning activities.

PP No.19 of 2005 concerning national education standards, article 1 paragraph 8 which states that the standard of facilities and infrastructure is the National Education Standard relating to minimum criteria regarding study rooms, sports places, places of worship, libraries, laboratories, workshops, places of worship. Play, a place for recreation and creativity, as well as other learning resources needed to support the learning process, including the use of information and communication technology. Therefore, every educational institution, both formal and non-formal, must provide facilities and infrastructure or facilities that meet the needs for the development of each student in terms of increasing their intellectual intelligence such as providing books in the library so that they can be a place to find material as a reference for student learning. In social improvement such as the providing of a prayer room in schools for spirituality. In this place, student can build friendships with school members and laboratories to interact each other in doing research, development tasks and field for students to do hobbies.

\section{a. Facilities and Infrastructure Planning}

Based on the provisions of the National Education Standards Agency, each education unit must be able to plan the procurement of school facilities and infrastructure to make the teaching and learning process effectively and efficiently. Based on the Minister of Home Affairs Regulation No. 17 of 2007 (Nurbaiti, 2015: 538) concerning technical guidelines for the management of regional property in Chapter III Article 7 paragraph (1) states that the planning for regional property needs is prepared in the work plan and budget of the regional work unit after taking into account the availability of regional property owned by the region. Planning is the first stage of the management of facilities and infrastructure which is also the procurement step. Bafadal stated that the planning process for educational facilities and infrastructure is as follows:

1. Accommodate all proposals for the procurement of school equipment submitted by each work unit and or take an inventory of school equipment shortages.

2. Prepare a plan for school supplies needs for a certain period, for example for one quarter or one school. 
3. Integrate the needs plan that has been prepared with previously available equipment by knowing the equipment owned by the school is reading the inventory book. Then arrange items that are not yet available at school.

4. Integrate needs plans with available school funds or budgets. In this case, if the available funds are not sufficient to procure all the necessary needs, it is necessary to make a selection of all the equipment needs that have been planned by looking at the urgency of each equipment needed.

5. Integrating the plan (list) of urgent equipment needs with the available funds or budget, it is necessary to hold another selection by looking at the priority scale.

6. Determination of the final procurement plan.

Planning for the procurement of school facilities and infrastructure must concern on the following:

a. Conformity with needs

b. Conformity with the amount and not too much or too little,

c. Keep good quality so that it can be used effectively,

d. The type of tool or item needed must be appropriate and increase work efficiency.

Planning is the first stage in the management of educational facilities and infrastructure, where planning must be prepared properly and must be adapted to what is needed by the school.

\section{b. Procurement of Facilities and Infrastructure}

Nurbaiti (2015: 539) states that the procurement of school facilities and infrastructure is carried out by; 1) drooping, 2) buying, 3) donations from parents, and 4) making your own.

1. Dropping, is assistance provided by the government to schools. It is carried based on procedures,: (a) analyzing the needs and functions of facilities and infrastructure; (b) classifying the facilities needed, (c) making proposals for the procurement of facilities and infrastructure to the government. And (d) after approval, the facilities and infrastructure mentioned will be sent to the schools that apply for the procurement of facilities and infrastructure.

2. Buying, which is done by direct purchase, namely purchases made to meet the needs of small quantities. The way to buy is to compare which of the suppliers to get the same material at a cheaper price. 
3. Asking for donations from the school's guardians or the community, such as holding a meeting with the school committee and parents to jointly think about the facilities and infrastructure needed by the school for the smooth teaching and learning process. This was done because of the lack of funds owned by the school. Make your own, The school facilities that are made are usually in the form of teaching aids used to assist the process of teaching and learning activities. This facility is made by teachers and students.

4. Procurement of facilities and infrastructure must be reviewed based on the needs of the school and not from the wishes of the school. For financing the procurement of facilities and infrastructure itself is conducted through assistance from the government and also donations from parents or the surrounding community.

\section{Maintenance of Facilities and Infrastructure}

Nurbaiti (2015: 543) also said that the maintenance of facilities and infrastructure or facilities in schools must be carried out optimally and consistently to make them ready to use in improving of performance and extending of the service life of facilities and infrastructure. It is also avoid the occurrence of accidents such as more fatal damage. Then, how to maintain school facilities and infrastructure, the description on the following:

1. Maintenance must be carried out every day

2. Always kept clean, used when needed and stored in its place after use,

3. Always check the facilities and infrastructure in schools to ensure the feasibility of these facilities and infrastructure,

4. Conduct inspections of damaged facilities and infrastructure and then repair them.

5. Periodic maintenance is carried out on school buildings and fences.

\section{Removal of Facilities and Infrastructure}

Regulation of the Minister of Finance Number 96/pmk.06/2007 concerning procedures for implementing the use, utilization, elimination, and transfer of state property. Nurbaiti (2015:545) states that the deletion has stages:

1. The school removes school facilities and infrastructure that are no longer used,

2. The process of removing facilities and infrastructure that are no longer used is carried out by storing them in a cupboard, 
3. Deletion is carried out on irrelevant and damaged textbooks.

In order that the existing school facilities and infrastructure can be accounted for for their use and utilization, the elimination of irrelevant and damaged facilities and infrastructure should be carried out by means of auction and destruction. Therefore, the deletion is made with careful planning and a notification letter is made to the superior by stating what items will be removed or abolished, Nurbaiti (2015: 546).

\section{DISCUSSION}

Yamin and Maisah (Darmastuti \& Karwanto, 2014:15) state that in improving the quality of learning, there are several components that can affect learning, namely (a) students, including the socio-economic, cultural and geographical environment, intelligence, personality, talents and interests; (b) teachers, covering educational background, work experience, teaching load, economic conditions, work motivation, commitment to work, discipline and creativity; (c) curriculum, (d) educational facilities and infrastructure, including teaching aids or practical tools, laboratories, libraries, skills room, Counseling Guidance room, UKS room and multipurpose room, (e) school management, including classroom management, teacher management, student management, facilities and infrastructure, improvement of discipline, and leadership, (f) management of the learning process, including teacher appearance, mastery of material or curriculum, use of learning methods/strategies, and utilization of learning facilities, (g) fund management, including planning budget (RAPBS), sources of funds, use of funds, reports and supervision; (h) monitoring and evaluation, including the Principal as a supervisor in his school, school supervisor, and the school committee as a supervisor, and (i) commitment, covering the school's relationship with government agencies, relations with the business world and community leaders, and other educational institutions.

Each subject has a different character from other subjects. Thus, each subject also requires different learning tools. In organizing learning, teachers certainly need facilities that can support their performance to take place in an interesting way. by supporting of adequate learning facilities, the teacher not only conveys the material orally, but also in writing and demonstration based on the infrastructure that has been prepared by the teacher. Teachers need learning facilities to support learning activities. In addition to the ability of teachers to organize learning activities, support from learning facilities is very important in helping teachers. The more complete and adequate learning facilities 
owned by a school will make it easier for teachers to carry out their duties as educational staff. Learning facilities must be developed in order to support the teaching and learning process. Yamin (Prastyawan, 2016:43) mentions several things that need to be developed in supporting the teaching and learning process: 1) libraries, 2) supporting facilities for curriculum activities, and 3) infrastructure and facilities for extracurricular and mulok activities. The teaching and learning process will be more effective and quality if it is supported by complete and adequate facilities and infrastructure. The teaching and learning process is a series of activities carried out by teachers and students by utilizing available facilities and infrastructure to obtain optimal learning outcomes. Thus, without educational facilities and infrastructure, it can be said that the educational process is less meaningful. To maximize the use of educational facilities and infrastructure optimally, it is necessary to have a management so that the educational goals that have been set can be achieved perfectly.

Melaya (2019:81) states that in order for the educational facilities and infrastructure needed by schools to function optimally in supporting learning in schools, it is necessary for school residents (principals, teachers, and administrative staff) who understand and are able to manage educational facilities and infrastructure professionally. This is in line with the policies outlined by the Ministry of Education and Culture regarding competency standards that must be possessed by school residents. One of the competencies that must be possessed by school residents is school managerial competence, namely school principals must have the ability to manage school facilities and infrastructure in the context of their optimal utilization.

\section{CONCLUSION}

Management of educational facilities and infrastructure is the process of how to organize or supervise educational infrastructure as well as how to procure educational facilities in educational institutions to achieve certain goals. Educational facilities and infrastructure are supporting factors in the teaching and learning process, so that the teaching and learning process can run smoothly. Basically the management of educational facilities and infrastructure at an educational institution such as a school must include several things that must be done, namely starting with planning, facilities and infrastructure, procurement of facilities and infrastructure, maintenance of facilities and infrastructure, and also the elimination of facilities and infrastructure. Infrastructure can be managed properly. 
In the management of facilities and infrastructure in schools, it must be managed properly with good planning to reach and achieve the hopes and main goals of the education. For this reason, concern on the management of all facilities and infrastructure or equipment in schools must indeed be prioritized for the realization of the main goal of this equipment to support successful learning. The purpose of managing school facilities and infrastructure is to provide professional services related to facilities and infrastructure education to create efficient and effective learning process.

\section{REFERENCESS}

Ananda, Rusydi \& Oda Kinata Banurea. (2017) Manajemen Sarana dan Prasarana Pendidikan. Medan: CV Widya Puspita.

Darmastuti, Hajeng \& Karwanto. (2014). Manajemen Sarana dan Prasarana dalam Peningkatan Kualitas Pembelajaran Pada Jurusan Teknik Komputer dan Informatika di SMKN 2 Surabaya. Jurnal Inspirasi Manajemen Pendidikan, Vol.3 No.3, Januari.

Ellong, Tubagus Djaber Abeng. (2018) Manajemen Sarana dan Prasarana Pendidikan di Lembaga Pendidikan Islam. Jurnal Pendidikan Islam Iqra. Volume 11 Nomor 1 Fakultas Tarbiyah IAIN Manado.

Kompri. (2015). Manajemen Pendidikan-2. Bandung: Alfabeta.

Kurniawan, Nurhafit. (2017) Pengaruh Standart Sarana dan Prasarana Terhadap Efektifitas Pembelajaran di TK Al-Firdaus. Jurnal Warna: Jurnal Pendidikan dan Pembelajaran Anak Usia Dini. September 2017. Vol 02. No. 02.

Kurniawati, Putri Isnaeni \& Suminto A. Sayuti. (2013). Manajemen Sarana dan Prasarana di SMKN 1 Kasihan Bantul. Jurnal Akutabilitas Manajemen Pendidikan Volume 1, Nomor 1,

Matin. Dan Nurhatti Fuad. (2016). Manajemen Sarana dan Prasarana Pendidikan. Jakarta: PT Raja Grafindo Persada,

Megasari, Rika. (2014). Peningkatan Pengelolaan Sarana dan Prasarana dalam Meningkatkan Kualitas Pembelajaran di SMPN 5 Bukit Tinggi. Vol 2 Nomor 1 Juni, Jurnal Administrasi Pendidikan,

Nasruddin \& Mayadi. (2019). Manajemen Sarana dan Prasarana Pendidikan Dalam Pembelejaran di SD. ISSN 1907-4034.

Nurbaiti. (2015). Manajemen Sarana dan Prasarana Sekolah. Manajer Pendidikan, Volume 9, Nomor4, Juli 2015. 
Prastyawan. (2016). Manajemen Sarana dan Prasarana. Al-Hikmah jurnal keislaman Volume 6 Nomor 1 Maret.

Rahayu, Suri Margi \& Sutama. (2015) Pengelolaan Sarana dan Prasarana Pendidikan Sekolah Menengah Pertama. Jurnal Varia Pendidikan, Vol. 27 No. 2 Desember.

Safingudin, Ahmad. (2020). Manajemen Sarana dan Prasarana Pendidikan Dalam Meningkatkan Mutu Lulusan di MTs Negeri Triwarno Kutowinangun Kebumen. Jurnal Cakrawala: Studi Manajemen Pendidikan Islam dan Studi Sosial P-ISSN: 2580-9385, E-ISSN: 2581- 0197 Vol.4 No.1.

Sairi, Asril, \& M. Safrijal. (2008) Pengaruh Mutu Layanan Sarana dan Prasarana Terhadap Kepuasan Siswa. Jurnal Manajemen, Kepemimpinan, dan Supervisi Pendidikan. Volume 3, No. 1, Januari-Juni.

Sari, Milya. (2020) Penelitian Kepustakaan (Library Reseacrh) dalam Penelitian Pendidikan IPA. ISSN 2715-470. Natural Science: Jurnal Penelitian Bidang IPA Dan Pendidikan IP A.

Setiawati, Ayu Yulia. (2018)Manajemen Sarana dan Prasarana Pendidikan Dalam Meningkatkan Mutu Pembelajaran di MAN 1 Yogyakarta. Tesis Universitas Islam Indonesia.

Sinta, Ike Melaya. (2019) Manajemen Sarana dan Prasarana. Jurnal Isema. Vol 4. Nomor 1, Juni.

Yulius, Mellky. (2020). Strategi MeningkatkanMutu Pendidikan Melalui Manajemen Sarana dan Prasarana Pada SMK Negeri 1 Singkawang. Khazana Pendidikan. Jurnal Ilmiah Pendidikan. Volume XIII. Nomor 2, Maret. 